\title{
IMPACT OF COVID- 19 ON PRIVATE SECTOR BUS EMPLOYEES WITH SPECIAL REFERENCE TO IRINJALAKUDA MUNICIPALITY
}

\author{
Silpa M A ${ }^{1}$, Dr. Umesh $\mathbf{U}^{2}$ \\ ${ }^{1}$ Research Scholar, Department of Commerce, Panampilly Memorial Government College, Chalakudy, Thrissur \\ ${ }^{2}$ Assistant Professor and Research Supervisor, Department of Commerce and Management Studies, Amal College of \\ Advanced Studies, Myladi, Nilambur
}

\begin{abstract}
The COVID-19 pandemic has affected all fields of human life. The people irrespective of their age, gender, occupation, education and country of living are suffering a lot due to the wide spread of COVID-19. Education sector, public transport sector, banking sector, food processing sector, etc. has experienced a drastic change due to the outbreak of corona virus. Out of these, public transport sector has suffered too much. Due to the lock-down, public transport was forced to stop their services. Road transport system especially, private buses suffered huge losses. It created unemployment among the bus employees. Bus employees faced not only financial problems but also unique health and safety problems that are not being addressed by their employers and policy makers at all level. An attempt is made to study the impact of Covid- 19 on the life of private sector bus employees.
\end{abstract}

Key words : COVID-19 pandemic, Private sector, Bus employees, Lock down

\section{INTRODUCTION:}

Private buses are playing a very crucial role in the social and economic development of Kerala. The State had, in the past, a unique and enterprising model in providing public transport services. Nowadays, the private bus industry in the state is collapsing day by day due Covid crisis. The second Covid wave has hit them hard. Despite hardship, private bus operators to continue services in Kerala. While bus services were restored after a long break during the lockdown, private bus operators were struggling to get services back to pre-Covid level. It created unemployment among the bus employees. Bus employees faced not only financial problems but also unique health and safety problems that are not being addressed by their employers and policy makers at all level. The purpose of this study is to analyse the impact of Covid -19 on the life of private sector bus employees.

\section{STATEMENT OF THE PROBLEM:}

Buses are the most widely-used form of public transport in Kerala, serving cities as well as suburban and rural areas. Buses improve social inclusion, which enable people to get access to the place of education, employment, healthcare, etc. - including those with low incomes, those who do not drive, the older generation, people with disabilities and people living in remote areas. The wide- spread of Covid-19 has made drastic changes in private bus sector. The private bus operators as well as bus employees faced a lot of problems due to the unemployment created by Covid-19 lock down and the continuing Covid restrictions. The current study is an attempt to analyse the impact of Covid- 19 on the life of private sector bus employees with special reference to Irinjalakuda municipality, Thrissur district.

\section{OBJECTIVES OF THE STUDY:}

1. To identify the problems faced by private sector bus employees due to Covid-19.

2. To understand the safety consciousness of private sector bus employees during Covid-19.

3. To understand the measures adopted by bus employees and government cope up with the problems due to Covid-19. 
International Advanced Research Journal in Science, Engineering and Technology

Vol. 8, Issue 9, September 2021

DOI: $10.17148 /$ IARJSET.2021.8949

REVIEW OF LITERATURE:

1. Julia Bird, Sebastian Kriticos and Nick Tsivanidis conducted a study on "Impact of COVID-19 on Public Transport". It reveals that, public transport has been hit hard by COVID-19. Many bus operators have had no choice but to scale back or completely shut down less viable routes; while others are passing their costs onto consumers.

2. Arab Trade Union, International Transport Workers' Federation and Danish trade union conducted a study on "Impact of the Covid 19 on the Transport Industry". It states that, Transport workers in precarious jobs or the informal economy, have suffered from lockdowns everywhere. They are paying a high price, losing their jobs and livelihoods without enjoying proper protection in social security. This leaves many of them in poverty, unable to feed their families. Universal social protection is therefore needed more than ever.

3. Dr. M K Durgamani , Mr. R V Suresh and Mr. G Sethuraman conducted a study tited "Occupational Stress among Private Bus-Drivers and Conductors in Thanjavur District". The study found that, Bus drivers and conductors when compared to workers of other jobs are more likely to exposed to stress due to conflicting demands like ensuring safety of the passengers, dealing with heterogeneous and erratic passengers, earning profit for bus operators, following traffic rules, work-life balance, handling unexpected incidents like accidents and many more. Job security is the root cause of stress among the private bus drivers and conductors.

4. Jeremy Sung and Yannick Monschauer conducted a study "Changes in Transport Behaviour during the Covid19 Crisis" which reveals that, the restrictions put in place to limit the diffusion and impacts of Covid-19 have had a widespread impact on people's lives. One of the biggest impacts has been the reduction in passenger transport demand, due to a combination of government lockdowns and fears of contracting and spreading the virus when using mass transport modes.

\section{RESEARCH METHODOLOGY:}

Descriptive research design is followed for conducting the study. Both primary and secondary data have been used. Primary data collected using structured questionnaire and secondary data collected from websites, news, journals and magazines. Population of the study includes private sector bus employees having their bus service in Irinjalakuda municipality. Convenient sampling method is used. Sample size is 60. Simple percentage analysis and Likert scale have been used for the study.

\section{DATA ANALYSIS AND INTERPRETATION:}

Table 1: Problems faced by bus employees due to Covid-19

\begin{tabular}{|l|l|l|}
\hline Problems & No. of respondents & Percentage of respondents \\
\hline Financial problems & 37 & 62 \\
\hline Physical problems & 12 & 20 \\
\hline Mental stress & 11 & 18 \\
\hline Total & 60 & 100 \\
\hline
\end{tabular}

From the above table it is clear that, about 62 percentage of employees have faced financial problems due to Covid-19.

Table 2: Reasons for the financial problems

\begin{tabular}{|l|l|l|}
\hline Reasons & No. of respondents & Percentage of respondents \\
\hline Unemployment & 32 & 54 \\
\hline Reduction in salary & 12 & 20 \\
\hline Increase in expenditure & 2 & 3 \\
\hline Others & 14 & 23 \\
\hline Total & 60 & 100 \\
\hline
\end{tabular}

From the above table it is clear that, about 55 percentage of employees have faced unemployment which is the main reason for their financial problem. 
International Advanced Research Journal in Science, Engineering and Technology

Vol. 8, Issue 9, September 2021

DOI: $10.17148 /$ IARJSET.2021.8949

Table 3: Whether the employees are cautious about their safety after lockdown

\begin{tabular}{|l|l|l|}
\hline Particulars & No. of respondents & Percentage of respondents \\
\hline Never & 2 & 3 \\
\hline Rarely & 5 & 9 \\
\hline Sometimes & 35 & 58 \\
\hline Very often & 3 & 5 \\
\hline Always & 15 & 25 \\
\hline Total & 60 & 100 \\
\hline
\end{tabular}

From the above table it is clear that, about 58 percentage of employees are sometimes cautious about their safety during Covid-19 situation.

Table 4: Whether the employees have any alternative job during lock down period

\begin{tabular}{|l|l|l|}
\hline Particulars & No. of respondents & Percentage of respondents \\
\hline No & 36 & 60 \\
\hline Yes & 24 & 40 \\
\hline Total & 60 & 100 \\
\hline
\end{tabular}

The above table states that, about 60 percentage of the bus employees had alternative jobs for their livelihood during lockdown period.

Table 5: Satisfaction level of bus employees with their alternative jobs

\begin{tabular}{|l|l|l|}
\hline Satisfaction & No. of respondents & Percentage of respondents \\
\hline Highly dissatisfied & 16 & 45 \\
\hline Dissatisfied & 4 & 11 \\
\hline Neutral & 5 & 14 \\
\hline Satisfied & 8 & 22 \\
\hline Highly satisfied & 3 & 8 \\
\hline Total & 36 & 100 \\
\hline
\end{tabular}

The above table states that, about 45 percentage of the employees are highly dissatisfied with their alternative job.

Table 6: whether the employees got any support directly or indirectly from the part of government

\begin{tabular}{|l|l|l|}
\hline Particulars & No. of respondents & Percentage of respondents \\
\hline No & 0 & 0 \\
\hline Yes & 60 & 100 \\
\hline Total & 60 & 100 \\
\hline
\end{tabular}

The above table shows that, 100 percentage of the bus employees got financial support from the government during the lockdown period.

Table 7: Strategies adopted by the government to overcome the problems of public transport sector during Covid19

\begin{tabular}{|l|l|l|}
\hline Strategies & No. of respondents & Percentage of respondents \\
\hline Tax exemption & 49 & 81 \\
\hline Increased bus fare & 49 & 82 \\
\hline Insurance claim & 54 & 90 \\
\hline Extension of renewal & 55 & 92 \\
\hline
\end{tabular}

From the above table it is clear that, the government has adopted many strategies to help public transport system to overcome the problems due to Covid-19. 
International Advanced Research Journal in Science, Engineering and Technology

Vol. 8, Issue 9, September 2021

DOI: $10.17148 /$ IARJSET.2021.8949

Table 8: Satisfaction with the strategies adopted by the government

\begin{tabular}{|l|l|l|}
\hline Satisfaction & No. of respondents & Percentage of respondents \\
\hline Highly dissatisfied & 28 & 47 \\
\hline Dissatisfied & 9 & 15 \\
\hline Neutral & 10 & 17 \\
\hline Satisfied & 9 & 15 \\
\hline Highly satisfied & 4 & 6 \\
\hline Total & 60 & 100 \\
\hline
\end{tabular}

The above table states that, 47 percentage of the employees are highly dissatisfied with the strategies adopted by the government to support public transport sector.

\section{RESULTS AND DISCUSSION:}

1. Covid-19 has created severe financial problems among private sector bus employees. They have faced many physical problems and mental stress too.

2. Bus employees have faced unemployment due to Covid-19 which is the major reason for their financial problem. 3. One fourth of the bus employees are always cautious about their safety during Covid-19 situation.

4. Majority of the bus employees had alternative jobs during lockdown, but they were highly dissatisfied with their alternative jobs.

5. All the bus employees got financial support from the government during lockdown period.

6. Government has provided tax exemption, increased bus fare and extended renewal dates which was helpful to the public transport sector to face the problems due to Covid -19 .

7. Majority of the employees are highly dissatisfied with the strategies adopted by the government to support public transport sector during Covid-19.

\section{CONCLUSION:}

Covid-19 imposed lockdown and additional measures such as physical distancing and frequent cleaning which has put an additional financial burden on the bus operators. The ban on bus services due to lockdown created unemployment among bus operators as well as bus employees. The study has provided an insight into the problems faced by the bus employees working in private sector. Due to unemployment bus employees were forced to find alternative jobs during lock down. Majority of them has found alternative jobs, but they were not actually satisfied with their job. Government has adopted many measures for supporting public transport sector, but need to give more consideration to the problems of bus employees working in private sector.

\section{REFERENCES:}

1. Dr. Gurpreet Randhawa and Dr. Summi Arora (2020). Factors Influencing Quality of Work Life of Bus Drivers of Public Transport in Punjab. Pacific Business Review International, 13 (4). 52-62.

2. Arab Trade Union, International Transport Workers' Federation and Danish trade union (2020). Impact of the Covid 19 on the Transport Industry. Report of International Trade Union Confederation.

3. Luyu Liu, Harvey J Miller and Jonathan Scheff (2020). The impacts of COVID-19 pandemic on public transit demand in the United States. PLOS ONE. November 18, 2020.

4. Dr. R. Rangarajan (2018). A Study on Job Stress and Job Satisfaction in Transport Sector- With Special Reference to MTC Bus Drivers in Adyar Depot. ResearchGate, 8 (4).

5. Dr. S Thirumaran and D Baranitharan (2016). Job Stress among Transport Employees in Cuddalore district. International Journal of Multidisciplinary Research and Modern Education, 2 (2), 275-280.

6. Victor S. and Desanits (1996), Comparing job satisfaction among public- private employees. The American Review of the public Administration, 26 (3), 327-343.

7. Pooja Dahiya; Roopsi Kaushik; Anil Sindhu. "Corona virus: an Overview Along with Its Alternative Diagnostic Measures". International Research Journal on Advanced Science Hub, 2, Special Issue ICARD 2020, 2020, 163-169. doi: 10.47392/irjash.2020.113

8. Salini Suresh; Suneetha V; Niharika Sinha; Sabyasachi Prusty; Sriranga H.A. "Machine Learning: An Intuitive Approach In Healthcare". International Research Journal on Advanced Science Hub, 2, 7, 2020, 67-74. doi: 10.47392/irjash.2020.67 